\title{
IfIISGUC.ORG
}

"iş, GÜÇ" ENDÜSTRi iLIŞKILERI VE INSAN KAYNAKLARI DERGISi

"IS, GUC" INDUSTRIAL RELATIONS AND HUMAN RESOURCES JOURNAL

\section{Türk İKY Anlayışı İle Japon İKY Anlayışı Arasındaki İşe Alma Yöntemleri Farklılıkları}

\author{
Prof.Dr.Serkan BAYRAKTAROĞLU
}

Sakarya Üniversitesi, İşletme Fakültesi

Ebru DURAL

Temmuz/July 2014, Cilt/Vol: 16, Sayi/Num: 3, Page: 19-34

ISSN: 1303-2860, DOI: 10.4026/1303-2860.2014.0253.x

Makalenin on-line kopyasına erişmek için / To reach the on-line copy of article:

http://www.isguc.org/?p=article\&id=551\&cilt=16\&sayi=3\&yil=2014

Makale İçin İletişim/Correspondence to:

Serkan BAYRAKTAROĞLU, Sakarya Üniversitesi, email: serkanb@sakarya.edu.tr 


\author{
Temmuz/July 2014, Cilt/Vol: 16, Sayı/Num: 3, Page: 19-34 \\ ISSN: 1303-2860, DOI: 10.4026/1303-2860.2014.0253.x
}

\begin{abstract}
İş, Güç, Endüstri İlişkileri ve İnsan Kaynaklan Dergisi, yılda dört kez yayınlanan hakemli, bilimsel elektronik dergidir.
Çalışma hayatına ilişkin makalelere yer verilen derg inin temel amacı, belirlenen alanda akademik gelişime ve paylaşıma katkıda bulunmaktadır.

İş, Güç, Endüstri İlişkileri ve İnsan Kaynaklan Dergisi, 'Türkçe' ve 'İngilizce' olarak iki dilde makale yayinlanmaktadır.

Dergimiz İş, Güç; ulusal ve uluslararası birçok indekste taranmaktadır. (Cabells Directory, Ebsco Socindex, Index Islamicus, Index Copernicus, Worldwide Political Science Abstracts, Sociological Abstract, Ulakbim Sosyal BilimlerVeritan, Asos Index)
\end{abstract}

\section{Editörler Kurulu / Editorial Board}

Aşkın Keser (Uludă̆ University)

K.Ahmet Sevimli (Uludă̆ University)

Şenol Baştürk (Uludă̆ University)

Editör/Editor in Chief

Şenol Baştürk (Uludağ University)

Uygulama / Design

Yusuf Budak (Kocaeli University)

Tarandı̆̆ı Indeksler/Indexes

ASOS INDEX

CABELLS DIRECTORY

EBSCO SOCINDEX

Index ISLAMICUS

Index COPERNICUS

Sociological Abstract

ULAKBIM Sosyal Bilimler

Veritanı

Worldwide Political Science

Abstracts

\author{
Yayın Kurulu / Editorial Board \\ Yrd.Doç.Dr.Zerrin Fırat (Uludă̆ University) \\ Prof.Dr.Aşkın Keser (Uluda ̆̆ University) \\ Prof.Dr.Ahmet Selamoğlu (Kocaeli University) \\ Yrd.Doç.Dr.Ahmet Sevimli (Uluda ̆̆ University) \\ Doç.Dr.Abdulkadir Şenkal (Kocaeli University) \\ Doç.Dr.Gözde Yılmaz (Marmara University) \\ Yrd.Doç.Dr.Dr.Memet Zencirkıran (Uludă̆ University)
}

Uluslararası Danışma Kurulu / International Advisory Board

Prof.Dr.Ronald Burke (York University-Kanada)

Assoc.Prof.Dr.Glenn Dawes (James Cook University-Avustralya)

Prof.Dr.Jan Dul (Erasmus University-Hollanda)

Prof.Dr.Alev Efendioğlu (University of San Francisco-ABD)

Prof.Dr.Adrian Furnham (University College London-Ingiltere)

Prof.Dr.Alan Geare (University of Otago- Yeni Zellanda)

Prof.Dr. Ricky Griffin (TAMU-Texas AEM University-ABD)

Assoc. Prof. Dr. Diana Lipinskiene (Kaunos University-Litvanya)

Prof.Dr.George Manning (Northern Kentucky University-ABD)

Prof. Dr. William (L.) Murray (University of San Francisco-ABD)

Prof.Dr.Mustafa Özbilgin (Bruner University-UK)

Assoc. Prof. Owen Stanley (James Cook University-Avustralya)

Prof.Dr.Işık Urla Zeytinoğlu(McMaster University-Kanada)

Ulusal Danışma Kurulu / National Advisory Board

Prof.Dr.Yusuf Alper (Uludă̆ University)

Prof.Dr.Veysel Bozkurt (İstanbul University)

Prof.Dr.Toker Dereli (Işık University)

Prof.Dr.Nihat Erdo ğmuş (İstanbul Şehir University)

Prof.Dr.Ahmet Makal (Ankara University)

Prof.Dr.Ahmet Selamoğlu (Kocaeli University)

Prof.Dr.Nadir Suğ ur (Anadolu University)

Prof.Dr.Nursel Telman (Maltepe University)

Prof.Dr.Cavide Uyargil (İstanbul University)

Prof.Dr.Engin Yildirm (Anayasa Mahkemesi)

Doç.Dr.Arzu Wasti (Sabancı University)

Dergide yaymlanan yazılardaki görüşler ve bu konudaki sorumluluk yazarlarma aittir.

Yaymlanan eserlerde yer alan tüm içerik kaynak gösterilmeden kullanılamaz.

All the opinions written in articles are under responsibilities of the outhors.

The published contents in the articles cannot be used without being cited 


\title{
Türk İKY Anlayışı İle Japon İKY Anlayışı Arasındaki İşe Alma Yöntemleri Farklılıkları
}

\author{
Prof.Dr.Serkan BAYRAKTAROĞLU \\ Sakarya Üniversitesi, İşletme Fakültesi
}

\section{Ebru DURAL}

\section{ÖZET}

Bu çalışmada, insan kaynaklarının işe alma fonksiyonu konu edilmiş ve şu sorulara cevap a ranmıştır: "Türk ve Japon işletmeleri, işe alma yöntemleri bakımından farklılaşıyor mu? Farklılaşıyorsa, nedenleri nelerdir?”. Genel olarak Türk ve Japon IKY anlayışlarında işe alma yöntemleri açıklanmaya çalışılmış ve yukarıda belirtilen sorular araştırılmıştır. Araştırmada yarı-biçimsel görüşme ve katılımcı gözlem yöntemleri kullanılarak, Türkiye'de de faaliyet göstermekte olan Toyota incelenmiștir. Toyota Türkiye'de çalışan Türk çalışanlar ve Japon koordinatörlerle görüşme imkanı bulunmuş, yapılan görüşmelerde iki ülke arasında işe alma yöntemleri bakımından farklılıklar olduğu sonucuna ulaşılmıştır. Bu sonuç ve yapılan değerlendirmeler çerçevesinde, farklılaşmanın nedenlerine ilişkin çıkarımlar yapılmaya çalışılmıştır. Ana firma kültürü hakim olsa bile, çok uluslu bir firmanın farklı ülkelerdeki organizasyonlarının, uygulamada ana ülkeden farklı yöntemler izlemesinin mümkün olduğu sonucuna da varılmıştır.

Anahtar kelimeler: Insan Kaynakları Yönetimi, Uluslararası İnsan Kaynakları Yönetimi, İşe Alma Yöntemleri, Japon Yönetim Sistemi

\begin{abstract}
In this work, recruitment function of human resources is treated and looked for an answer to the questions of: "Do Turkish and Japanese entities differ in terms of recruitment? If they differ, what are the reasons?". In general, recruitment processes in Turkish and Japanese HRM understanding are tried to be explained and questions above are studied. In the study, Toyota, operates also in Turkey, has been examined by using semi-formal interview and participating observation methods. There has been the opportunity to meet with Turkish employees and Japanese coordinators. As a result, it was reached to the conclusion that there are differences between two countries in terms of recruitment methods. In the framework of this result and the evaluations made, it was tried to make assumptions about the reasons of differentiations. It has been reached to the conclusion that, although there is the controlling parent company culture, it is possible that the organizations of a multinational company in different countries use different methods than the home country in practice.
\end{abstract}

Keywords: Human Resources Management, International Human Resources Management, Recruitment Methods, Japanese Management System 


\section{GİRIŞ}

Kavramsal olarakinsan kaynakları, Türkiye'de daha çok "personel yönetimi" ile karıştırılmakla birlikte, yönetimsel bir yapı haline geldiği de gitgide kabul görmektedir. $\mathrm{Bu}$ anlamda insan kaynakları yönetimi, birçok farklı fonksiyonun birlikte, düzenli ve koordineli olarak işlemesini gerektirir. Kendisini oluşturan bu fonksiyonlar, işletmenin personel ihtiyacının belirlenmesi ile başlayıp personelin motivasyonunun sağlanmasına kadar uzanmaktadır. Hiç şüphe yok ki, bu fonksiyonlar arasında en önemlisi işe eleman bulma ve seçme, diğer bir ifade ile işe alma ve yerleştirme fonksiyonudur. Çünkü işletmeye doğru kişilerin, doğru zamanda ve doğru yöntemlerle seçilerek kazandırılması, hem işletme hem de çalışan bakımından önem arz eden bir noktadır.

Aday bulma ile başlayan işe alma ve yerleştirme fonksiyonu, ulusal ve uluslararası alanda farklı uygulama şekillerinde karşımıza çıkmaktadır. Konunun bu çalışmada ele alınan kısmı da uluslararası insan kaynakları yönetimini ilgilendirmektedir. Japonya'da işe alma yöntemleri ile Türkiye'de işe alma yöntemlerinin karşılaştırılması, bu çalışmanın konusunu oluşturmaktadır. Amaç; işe alma yöntemleri bakımından Türk işletmeleri ile Japon işletmelerinin farklılaşıp farklılaşmadığını araştırmak ve farklılaşıyorlarsa nedenleri üzerine çıkarımlarda bulunmaktır. İşe alma ve yerleştirme fonksiyonunun ulusal ve uluslararası alanda farklı şekilde uygulanma gerekliliği göz önünde bulundurulduğunda, çok uluslu bir işletmenin kendi uygulama şekillerini ve bakış açısını konuk olduğu ülkelerdeki organizasyonlarında da bire bir uygulaması mümkün olmamaktadır. Bu bağlamda Japon - Türk farklılaşmasını ele alan bu çalışma, Türkiye Japonya farklılaşmasını ortaya koymaya çalışması bakımından önem taşımaktadır. Aynı zamanda işe almada Japon uygulamalarının Türkiye'de uygulanıp uygulanmadığı sorusuna da cevap aramaya çalışması bakımından önemlidir.

\section{Türk Örgüt Yapısı İnsan Kaynakları Yönetiminde İşe Alma Yöntemleri}

Türkiye'de insan kaynakları yönetimi, genel insan kaynakları fonksiyonları çerçevesinde şekillenmektedir. Bu fonksiyonlar; işe alma ve yerleştirme, eğitim ve geliştirme, güdüleme, iş ve işgören değerleme, ücretleme, çalışma ilişkileri ve güvenlik, iletişim şeklinde karşımıza çıkmaktadır. Bu fonksiyonlardan “işe alma ve yerleştirme" bu çalışmaya konu olmuştur.

İşletmelerin sahip oldukları çalışan sayısı ile olması gereken çalışan sayısının karşılaştırılması ve çıkan sonuca göre çalışan sayısının sağlanmasına yönelik önlemler alınması, planlama sürecini oluşturur. Başka bir ifade ile insan kaynakları planlaması fonksiyonu, işletmelerde olması gereken çalışan miktarı ile olan çalışan miktarının dengelenmesini hedeflemektedir (Kaynak, 1996: 60). Bu fonksiyonun devamı ve tamamlayıcısı olan fonksiyon ise işe alma ve yerleştirme fonksiyonudur. Aday işe alma işlemlerine başlamadan evvel yapılması gereken, aday temin etmektir.

\subsection{Türk İşletmelerinde Aday Sağlama Yolları}

İşletmelerde aday bulma ve personel seçme sürecinin başlatılma sebebi, herşeyden önce bir eleman ihtiyacının doğmuş olmasıdır. $\mathrm{Bu}$ ihtiyacı belirleyen şey ise, işletmenin yürüttüğü faaliyete bağlı olarak yaptığı iş tanımlaması ve iş analizleridir. Yani bir işletmede personel ihtiyacının olup olmadığına karar vermeden önce işler tanımlanmalı, analiz edilmeli ve her bir işin gereksinimleri ortaya çıkarılmalıdır. Böylelikle söz konusu işlerin yapılabilmesi için gereken personel ihtiyacı tespit edilmiş olacaktır. Başlangıçta yerine getirilen bu adimlar sayesinde, ileriki zamanlarda ortaya çıkacak eleman ihtiyaçları da zamanında tespit edilebilecektir.

İnsan kaynakları yönetiminde iş analizi yapıldıktan ve iş tanımı ve iş gereksinimleri hazırlandıktan sonra, başka bir deyişle iş'ler hakkında bilgi sahibi olduktan sonraki aşama, bu iş'leri yapacak nitelikli çalışanları iş yerine kazandırmaktır. Yani yapılacak iş ile bu iş'in 
yapılması için gerekli becerilere sahip olan çalışanları buluşturmaktır. İşletmenin iki önemli çalışan kaynağı vardır (Mirze, 2010: 178-179):

\subsection{1. İç Kaynaklar}

İşletme içinden işgören bulma politikası, örgütte mevcut insan kaynağından faydalanmadır (Kücü, 2007:6).

İç kaynaklardan eleman tedariki temelde iki şekilde olabilir.

a. Yükselme (terfi): Çalışan kıdem durumuna göre ya da performansa göre terfi ettirilebilir.

b. Yatay geçişler (iç transferler): İşletmenin departmanları arasında yatay olarak çalışanların yer değiştitilmesi yöntemidir.

\subsubsection{Dış Kaynaklar}

Pozisyonları doldurmak için yeterli sayıda dahili aday olmadığı varsayıldığında, muhtemelen dış adaylara - halihazırda şirket tarafından çalıştırılmayan adaylara odaklanılacaktır. Harici adayların öngörülmesi genel ekonomik durumu, yerel piyasa şartlarını ve iş piyasası şartlarını da kapsar (Dessler, 1991: 126).

Diş kaynaklardan eleman temin etmek için başvurulabilecek yöntemleri şöyle siralayabiliriz:

- Duyurular (ilanlar) : Gazeteler, dergiler, radyo ve televizyon ilanları

- Doğrudan başvuru ya da cv gönderme

- Aracılarla başvuru: İşletme içinden ya da dışından bazı kişilerin aracılığı ile işe alma (Sabuncuoğlu, 2000:81).

- İş ve İşçi Bulma Kurumu

- Özel insan kaynakları danışmanlık büroları

- Eğitim kuruluşları: Mesleki ve teknik konularda eğitim veren okullar ve yüksek okullar ile üniversitelerin zaman zaman düzenlediği kariyer günleri, işletme gezileri (Sabuncuoğlu, 2000:83).

- Sakat ve eski hükümlüler: İş Kanunu'nun 25.maddesinin A ve B bentlerine göre.

- İşgören kiralama (leasing) : Belirli süreliğine bir firma tarafından belirli sayıda işgörenin kiralanması esasına dayanmaktadır. Burada işe alınan işgörenler, aslında kiraya veren firmanın kadrolu elemanlarıdır (Kücü, 2007:11).

- İnternet.

- Diğer kaynaklar: Sendikal kuruluşlar, mesleki örgütler (Sabuncuoğlu, 2000:85).

Ayrıca, firma sahip ve yöneticilerinin y akınları ile mevcut çalışanların tavsiyeleri de personel bulmada ve işe alma sürecinde geçerli ve etkili bir yol olabilmektedir (Danışman, 2008: 19).

\subsection{Türk İşletmelerinde Personel Seçme ve Yerleştirme Süreci}

Personel seçimi, "iç ve/veya dış kaynaklar aracılığı ile müracaat eden kişiler arasından, işletmede personel açı̆̆ı oluşan ya da oluşabilecak görevlere, o işe uygun olan kişi ya da kişileri seçmektir" şeklinde tanımlanabilir. Ancak personel seçmenin tek bir faaliyet değil, uzun soluklu bir süreç olduğu unutulmamalıdir.

Tüm işletmeler tarafından kabul görmüş standart bir personel seçim süreci mevcut olmayıp, işletmenin büyüklüğü, işlerin karmaşıklığı ve işe alınacak personel sayısı vb. faktörlere göre her işletmede farklılık gösterebilmektedir. (Özgen ve Yalçın, 2010: 116-117).

Personel seçme temel olarak 8 adımdan oluşan bir süreçtir. Bu adımlar:

1. İlan ve Aday Kabulü

2. Ön Görüşme ve Başvuru Formu Doldurulması

3. Test - Sinav

4. İş Görüşmesi

5. Referansların İncelenmesi

6. Seçim Kararının Verilmesi

7. Sağlik Kontrolü

8. İşe Kabul ve Yerleştirme

Genel olarak Türk işletmelerinde, işe personel adayı bulma ve bulunan adaylar arasindan uygun personeli seçip onu/onları işe yerleştirme, yukarıda sayılan sekiz adımda gerçekleştirilmektedir. Japon işletmelerinde durumun nasıl olduğu, bir sonraki bölümde ele alınmıştır. 


\section{Japon Örgüt Yapısı İnsan Kaynakları Yönetiminde İşe Alma Yöntemleri}

Japon örgütlerinin kendilerine özgü geleneksel bir insan kaynakları yönetim sistemi bulunmaktadır ve bu sistemi William Ouchi "Z Teorisi" olarak adlandırmıştır. Bu teorinin temel özellikleri şu şekildedir (Hatvany and Pucik, 1991: 491; Mucuk, 1999: 183-184);

- Çalışanlara uzun dönemli istihdam

- Kolektif karar verme

- Diğer ülkelere nazaran seyrek performans değerleme ve terfi

- Aidiyet ve yakınlık duygusu yaratmak suretiyle aile havası içinde işbirliği

- Kişisel sorumluluk beklentisi

- Çalışan ve işveren arasında karşılıklı güven

- Az sayıda yönetim kademesi ve yönetim pozisyonu

- Çalışan için holistik/bütünsel endişe

- Örtülü denetim mekanizması

\subsection{Japon İşletmelerinde Aday Sağlama Yolları}

Japon işletmelerinde elemanlar, uzun dönemli olarak istihdam edildikleri için, işten ayrılmaları ya da çıkarılmaları genellikle söz konusu olamaz. Örgütün en alt basamaklarında göreve başlanır ve zaman içersinde kıdem sistemine göre üst basamaklara doğru yükselinir. Bu nedenle boşalan kadrolar öncelikle işletme içi kaynaklardan doldurulur (Tüz, 2001: 47).

\subsection{1. İç Kaynaklar}

Japon işletmelerin personel alımında, işletme içi kaynaklardan transfer ve yükselme yöntemlerinin her ikisi de kullanılır. Transfer yöntemi birim şefi düzeyine kadar uygulanır. Alt basamakta yer alan elemanlar, transfer yöntemiyle, birim şefinin ataması doğrultusunda, çeşitli faaliyetlerde görev alırlar. Transfer, aynı birim içersinde değişik faaliyetler için olabileceği gibi farklı birimler arasında da olur. Personel bölümü çekirdek görevlilere, faaliyete başladıktan itibaren ilk on yıl içersinde değişik birimler arasında en az iki yere transfer zorunluluğunu getirmiştir. Diğer bir deyişle yedi yıl sürekli olarak aynı birimde bulunma durumu söz konusu olamaz.
Transfer zorunluluğu, elemanların aynı görevde saplanıp kalmalarını önlemek, birden çok kişinin gözlem ve değerlendirmelerinden yararlanmak içindir. Birim şefinden daha üst basamaklar için genellikle transfer söz konusu olmaz. Dikey yapıya bağımlı olarak, yükselmeler gerçekleşir (Tüz, 2001: 48).

\subsubsection{Dış Kaynaklar}

İşletme dişı kaynaklar, alt basamaklara eleman alımında, özellikle örgütsel birimlerin doldurulmasında kullanılır. Alt kadroların genel eğitim seviyesi yüksek olan elemanlardan oluşmasına özen gösterilir. Bu amaçla ülkenin en seçkin üniversitelerinden yararlanılır. Üniversiteler eleman seçiminde bir süzgeç olarak kullanılırlar (Yoshino, 1968). Elemanlar, okulu bitirir bitirmez ilgili işletmeye müracaat ederler. Japonya'da bütün büyük işletmelerin müracaat tarihi aynıdır. Bu nedenle aynı yıl içersinde birkaç firmaya müracaat etme durumu söz konusu olamaz. Büyük işletmeler idare, okul ve üniversite yetkilileri ile yakın bağlar kurarak aday elemanlarin iyi kayıtlara sahip olup olmadıklarını öğrenirler. Bazıları ise öğretim üyeleri aracılığıyla, müracaat öncesi bağlantılara yönelirler. Eleman seçiminde kişilikleri ve yetiştirme biçimleri değişik olanların bir araya getirilmesine özen gösterilir. Atletler, öğrenci liderleri ve iktisattan edebiyata kadar farklı öğrenim dallarını bitirmiş elemanların karması düşünülür (Tüz, 2001: 47).

\subsection{Japon İşletmelerinde Personel Seçme ve Yerleştirme Süreci}

Japon örgütlerinde önceden iş deneyimi olan kişiler tercih edilmez. Örgütlerin işe alma kriterleri genelde adayların kişilik, karakter ve potansiyel yeteneklerinde yoğunlaşır. Başarılı bir adayın bunlardan en az birine sahip olması gerekir. Ancak genel olarak kişilik daha önemlidir. Bu da Japon kültürünün grup doğasından kaynaklanır. Örgüt ortamına uyum sağlayacak ve onu bozmayacak adaylar seçilir. Başka bir deyişle adayların eğitiminden çok karakterleri önemlidir. Zaten eğitim örgütte verilecektir. Japonlar becerinin öğretilebileceğini ancak kişilik özelliklerinin 
kolay kolay değişmeyeceğini düşündükleri için kişinin örgütsel uyumuna bakarlar. Önemli olan adayın örgütte uyum sorunu yasamaması ve mümkün olan en iyi okuldan mezun olmasıdır. Prestijli bir üniversiten mezun olmak büyük ölçekli örgütlere giriş vizesi olarak görülür (Robinson, 2003: 443; Pudelko, 2006: 153).

Yeni mezunların başvuru sağlama sürecini gerçekleştirmek üzere örgütlerin (genelde büyük ölçekli örgütlerin) insan kaynakları bölümleri başvuru sağlama ekipleri kurar. Bu ekipler en iyi üniversitelerden hedefler belirler ve proje ekibi gibi çalışır. Ekipte takım lideri kıdemli insan kaynakları yöneticisidir. Bunun yanında daha genç sorumlu insan kaynakları yöneticisi, insan kaynakları elemanları ve üniversiteden mezun on ya da yirmi eleman bulunur. İnsan kaynakları yöneticisi projenin lokomotifi gibidir ve her uygulamayı o yönlendirir. Bu uygulamalar için bir zaman çizelgesi hazırlanır. Her ekip belirli sayıda öğrenci ile yıllık görüşmeler düzenler. $\mathrm{Bu}$ görüşmeler; ilgi elemesi, yeni üyelerin seçimi, insan kaynakları yöneticisinin seçimi, takım liderinin seçimi ve son olarak insan kaynakları bölümünün genel yöneticisinin karar vermesi olmak üzere beş adımda gerçekleşir. Belirli sayıda yeni aday ilk elemeden geçerek yarı finale kalır. Daha sonra kişilik, potansiyel, yetenek gibi özelliklere bakılarak bir eleme daha gerçekleşir. Finalde ise takım liderleri her üyenin görüşünü alarak sonuçları ilgili bölüme sunar ve nihai karar üst yönetim tarafından verilir (Robinson, 2003: 445-448).

Türk işletmeleri ile Japon işletmelerinin personel seçme ve işe alma yöntemlerinin ne olduğu yukarıdaki iki bölümde anlatılmaya çalışılmıştır. Bir sonraki bölümde ise personel seçme ve yerleştirme yöntemleri bakımından iki ülkenin karşılaştırması yapılmaya ve gözlemlenen farklılıklar aktarılmaya çalışılacaktır.

\section{3. İşe Alma Yöntemleri Bakımından Türk Örgütleri İle Japon Örgütleri}

İşletmelerde personel temin ve seçimi süreci konusunda, Türk ve Japon firmaları arasında farklılaşma söz konusudur. Bu farklılaşmanın
İKY anlayışları ve onun da temelinde yatan "yönetim sistemi" anlayışları arasındaki farklılaşmadan kaynaklandığı söylenebilir. Türk ve Japon toplumları arasında, toplumsal kültürleri birbirine oldukça yakın olmasına rağmen, örgüt kültürü ve yönetim sistemleri bakımından farklılıklar olduğu düşünüldügüünde, İKY fonksiyonlarının uygulanması bakımından da farklılıkların olması son derece doğal olarak değerlendirilmelidir. Yanı sıra, yasal düzenlemeler arasındaki farklılık da İKY anlayışlarının farklılaşması konusunda bir etken olarak görülmektedir.

\subsection{Aday Kaynakları Bakımından Farklılıklar}

\section{a. Türkiye}

Firma için doğru kişilerin bulunabilmesi için günümüzde Türkiye'de faaliyette bulunan bir firmanın ulusal ve yerel gazete ilanları, internet, Türkiye İş Kurumu, özel istihdam büroları, firma içi transfer ve terfiler, yakın ve tanıdıkların tavsiyeleri, çalışanların tavsiyeleri, kariyer günleri ve mesleki fuarlara başvurması mümkündür (Danışman, 2008: 88-89). Bunların yanı sıra, işletme içinde yatay geçişler, terfiler ve atamalar ile de ihtiyaç duyulan eleman açı̆̆ı giderilmektedir. "İç kaynaklar" olarak ifade edilen bu aday kaynağı da Türkiye'de yaygın olarak (özellikle büyük ölçekli şirketlerde) kullanılmaktadır.

\section{b. Japonya}

Japon şirketleri için de tıpkı Türk şirketleri gibi iç ve dış kaynak kullanımı söz konusudur. Kavramsal olarak Türkiye ile benzerlik gösteren bu durum uygulamada farklılaşmaktadır. Uzun dönemli istihdam anlayışı, kıdeme göre terfi anlayışı, iş değiştirmenin hoş karşılanmaması ve işten çıkarılmanın utanç verici olduğuna inanılması sebeplerine bağlı olarak, Japon işletmelerinde işten ayrılma ya da çıkarılma sıklıkla rastlanan bir durum değildir. Bu nedenle boşalan pozisyonun yerini dışarıdan eleman alımı ile doldurmak gibi bir durum söz konusu olmamaktadır. İşe yeni başlayacak eleman, örgütün en alt basamaklarından işe başlar ve zaman içersinde yükselerek (kıdem) üst 
basamaklara doğru ilerler (terfi). Bu da boşalan kadroların iç kaynaklardan doldurulduğu anlamina gelmektedir.

Japon işletmelerinde işe alımlarda kaynak kullanımı özetlenecek olursa; "işe yeni ve en alt basamaklardan başlayacak kişilerin temini için işletme dışı kaynaklardan yararlanılırken, üst basamaklarda boşalan kadroların doldurulması için işletme içi terfilerden yararlanılır (yani iç kaynaklar kullanılır)" denilebilir.

Japon yönetim sistemine göre tecrübesiz ve eğitilebilir kişilerin şirkete alınması söz konusu olduğundan, adaylar okulu bitirir bitirmez iş başvurusu yapmaktadırlar. İşletmeler de adaylar ile ilgili olarak okulların referanslarına önem verdiklerinden, Japon işletmeleri için kastedilen "dış kaynak"ın "üniversiteler" olduğunu söylemek yanlış olmayacaktır.

\subsection{Personel Seçme Yöntemleri Bakımından Farklılıklar}

\section{a. Türkiye}

Türk işletmelerinde personel seçimi, uzun soluklu bir süreçten oluşmaktadır. Bu süreç içersinde iş ilanı ve adayların ilk başvurularının alınması, adayların ön elemeden geçirilip başvuru formu doldurmaları, çeşitli sınav ve/veya testlerden geçirilmeleri, mülakat (görüşme) yapıldıktan sonra referanslarının kontrol edilmesi, seçim kararının verilmesi ve sağlik kontrolünden sonra seçilen adayın işe yerleştirilmesi adımları izlenmektedir. Ancak bu seçim uygulamalarının kurumsal (veya İK departmanı olan) şirketlerde tam uygulanabildiğini belirtmekte yarar vardır. Orta ve küçük ölçekli işletmelerde durum bundan farklıdır. Bunlarda daha çok aday ile direkt olarak mülakat (görüşme) yapma yöntemi kullanılarak eleman seçilmeye çalışılmaktadır.

\section{b. Japonya}

Personel seçiminin yöntemi, bir diğer ifade ile personel seçim aracı ele alındığında, Japon işletmelerinin Türk işletmelerinden çok da farklılaşmadığını söylemek mümkündür. Japon işletmelerinde de personel seçim yöntemi (arac1) olarak mülakat (görüşme) yöntemi kullanılmaktadır. Görüşme yönteminin uygulanmasında genel bir hiyerarşi görülmektedir. Ön eleme görüşmelerinden sonra aday olarak belirlenen kişiler sırası ile insan kaynakları yöneticisi, takım lideri, insan kaynakları bölümünün genel yöneticisi ve son olarak üst yönetim ile görüşürler.

\subsection{Personel Seçim Kriterleri Bakımından Farklılıklar}

a. Türkiye

Personel seçim sürecinde adayların firmaya ve işe uygunluk açısından objektif bir şekilde değerlendirilmesinde faydalı olabilecek kişilik, yetenek ve mesleki testlerin uygulanma oranı, şu aşamada orta düzeyde olmakla birlikte, geçmiş yıllara göre gelişme eğiliminde bulunmaktadır. Ayrıca, işe alım kararında dikkate alınan ölçütler arasında, adayın başarı potansiyeli ve uyumluluğu, nitelik ve yetkinliği ile eğitim düzeyi yüksek düzeyde dikkate alınırken, yakınlık ve yaşam tarzı ölçütünün nispeten düşük oranda dikkate alındığı görülmektedir. Yakınlık ve yaşam tarzı, büyük firmalardan çok küçük ölçekli firmalarda işe alım ölçütü olarak kullanılmaktadır (Danışman, 2008: 200).

\section{b. Japonya}

Japon yönetim sistemine göre işe yeni başlayacak elemanlar, yeni mezun olmuş ve henüz iş tecrübesi edinmemiş adaylar arasından seçilmektedir. Adaylarda öncelikli olarak aranan özellikler kişilik ve karakterlerine yönelik özelliklerdir. Görülen eğitim ve diğer birikimler (sertifikasyon, yabancı dil vb.) kişinin artıları olarak görülür, ancak seçilme kriteri ve sebebi değildir. Japon şirketleri için önemli olan, adayın şirketin ortamına uyum sağlayabilecek, örgüt kültürünü benimseyebilecek ve eğitilebilir bir kişi olmasıdır. Gerekli eğitimler zaten şirket içinde verilecektir.

Kişilik ve karakter özelliklerinin dışında adaylarda dikkat edilen diğer kriterler, çalışma isteği, hırs, beceri, eğitim, aile yapısı, genel davranışları ve görünüşü şeklinde 
sıralanabilir. Ancak yüzdesel olarak en büyük pay, kişilik ve karakter özelliklerine aittir. Deneyim, aranan bir seçim kriteri değildir, çünkü Japon şirketleri deneyimi olmayan kişileri, kendi şirket kültürleri ile eğitmek ve direkt olarak kendi şirket kültürleriyle tecrübe sahibi etmek istemektedir. Önemli olan kişinin şirket kültürüne ayak uydurabilmesi ve şirket ortamını bozacak davranışlar sergilememesidir.

\subsection{Seçim Kararını Veren Bakımından Farklılıklar}

\section{a. Türkiye}

Şef pozisyonundaki kişiler ile teknik ve uzman personelin işe alım kararı, firmaların genelinde nihai olarak genel müdür ve üstü pozisyondaki yöneticiler tarafından verilirken, ofis personeli ile mavi yakalı personelin işe alım kararını genel olarak en son aşamada birim yöneticileri vermektedir. Diğer alanlarda olduğu gibi, Türkiye'de işe alım kararları da büyük ölçüde merkeziyetçi bir nitelik taşıyor gibi gözükmektedir (Danışman, 2008: 201).

\section{b. Japonya}

Japon şirketlerinde karar, Türkiye'de olduğu gibi tek bir kişi tarafından değil, bir ekip tarafından verilmektedir. Oldukça kalabalık olan bu ekipte lider kıdemli insan kaynakları yöneticisidir. Yanında insan kaynaklarının sorumlu yöneticisi, diğer insan kaynakları elemanları ve üniversite mezunu on veya yirmi kişi bulunur. Bu kalabalık ekip kendi içinde küçük ekiplere bölünür ve her ekip belli sayıda aday ile görüşerek ilk elemeleri yapar. $\mathrm{Bu}$ ilk elemelerden sonra kalan adaylar insan kaynakları yöneticisinin ve takım liderinin elemelerinden de geçerler ve adayların belirlenmesi ile ilgili nihai karar aşamasına gelinir. $\mathrm{Bu}$ karar ise insan kaynakları bölümünün genel yöneticisine aittir. Bu şekilde belirli bir sayıya indirilen adaylar çeşitli testlerden geçirilerek son eleme yapılır. Bundan sonra kalan adaylar hakkında takım liderlerinin görüşü alındıktan sonra, işe alım kararını vermek üzere üst yönetim devreye girer.

Japon şirketlerinde işe alma kararının verilmesi konusu, aslında işe alım sürecini de kapsamaktadır. Bu uzun soluklu süreçten de anlaşılacağı gibi, işe alım konusunda karara giden aşamalar bir ekip işi iken, nihai karar şirket üst yönetimi tarafından verilmektedir.

\subsection{Sonuç}

"İşe alma yöntemleri bakımından Türk şirketleri ile Japon şirketlerinin farklılaşması" konusu aşağıdaki tablo ile özetlenmiştir.

\section{Tablo 1: İşe Alma Yöntemleri Bakımından Türk ve Japon Şirketleri}

\begin{tabular}{|l|c|c|}
\cline { 2 - 3 } \multicolumn{1}{c|}{} & \multicolumn{1}{c|}{ Türk İşletmeleri } & Japon İşletmeleri \\
\hline Kaynak & Ağırlıklı olarak dış kaynaklar & Ağırlıklı olarak okullar \\
\hline Yöntem & Temel İK işe alma yöntemleri & Mülakat $\rightarrow$ Testler $\rightarrow$ Mülakat \\
\hline Kriter & Eğitim, tecrübe, yetenek, diğer. & Kişilik, karakter, uyum, diğer. \\
\hline Karar & Yöneticiler & İşe alım ekibi $\rightarrow$ Üst yöne tim \\
\hline
\end{tabular}


Tabloda da görüldüğü gibi, iki ülke arasında farklılıklar olduğu kadar benzer ya da birbirine yakın taraflar da bulunmaktadır. Örneğin; Japon işletmelerinde aday kaynakları okullar olarak görülse de aslında okullardan eleman temin etmek dış kaynak kullanımı anlamına gelmektedir $\mathrm{ki}$, bu da Türk işletmeleri ile benzerlik gösterdiği anlamını taşımaktadır. Benzer ve farklılaşan noktalar değerlendirildiğinde, "personel seçim sürecinde iki ülke arasında farklılaşmanın görüldüğü noktalar, belirlenen seçim kriterleri ile seçim sürecinin işlemesidir" demek yanlış olmayacaktır.

\section{Türk ve Japon Örgüt Yapılarında İşe Alma Yöntemlerine Yönelik Bir Araştırma}

\subsection{Amaç, Kapsam ve Yöntem}

İnsan kaynakları yönetiminin "işe alma" işlevinin konu edildiği bu çalışmada, "uygulamada ülkeler arası farklılaşma" ele alınmak istenmiş; çalışmaya, "insan kaynakları yönetiminde işe alma yöntemlerinin Japon ve Türk toplumlarındaki uygulamasının nasıl olduğu" sorusu ile yön verilmeye çalışılmıştır. İki ülkenin toplumsal kültürlerinin birbirine yakın olmasına rağmen, örgüt kültürü söz konusu olduğunda yönetim sistemlerinin farklılaştığı görülmüş ve bu farklılaşmanın nedenlerini ortaya koymak, bu çalışmada amaç edinilmiştir.

Genel olarak personel temin ve seçim süreci bakımından Türk ve Japon işletmeleri arasındaki farklılaşmayı incelemek amacını taşıyan bu çalışmada, örneklem olarak Toyota seçilmiştir. Ancak Toyota bir Japon firması olduğundan ve aynı platformda bir Türk şirketi inceleme imkanı olmadığından, Türk ve Japon işletmeleri arasındaki farklılaşmaya değinebilmek amacı ile Toyota'nın Japonya'daki organizasyonu ile Türkiye'deki organizasyonu değerlendirilmeye çalışılmıştır.

Toyota Türkiye ve Toyota Japonya örneklemi üzerinden yürütülen çalışmada yöntem "örnek olay incelemesi" olarak seçilmiş ve "yarı biçimsel mülakat" yönteminden yararlanılmıştır. Görüşmelerde alınan cevapların değerlendirilmesi aşamasında ise daha detaylı değerlendirmeler yapabilmek amacıyla "katılımcı gözlem" yöntemi kullanılmıştır.

\subsection{Kisitlar}

- Türk şirketleri ile Japon şirketleri arasında işe alım sürecinde görülen farklılıkların Toyota'nın Türkiye ve Japonya organizasyonları karşılaştırılarak ortaya konmaya çalışılması, aynı zamanda çalışmanın başlıca kısıdını oluşturmaktadır. Birden fazla Türk şirketi ile birden fazla Japon şirketinin incelenerek bu farklılıklar hakkında değerlendirme yapmak imkanı bulunmadığından böyle bir yol izlenmiştir.

- Bir diğer kısıt, Toyota'nın hem Türkiye hem de Japonya organizasyonları hakkındaki bilgilerin Toyota Türkiye üzerinden araştırılabilmesi, fakat Toyota Japonya ile doğrudan iletişim kurulamamasıdır. Bu kısıt sebebi ile Toyota Japonya hakkındaki bilgiler, Toyota Türkiye'nin deneyimli çalışanlarından edinilerek derlenmiştir.

- Son kısıt ise, görüşme yapılan çalışan sayısı kısıdıdır. Konu ile ilgili bölümlerde görev yapmış ya da halen yapmakta olan her çalışan ile görüşme yapmak imkanı olmadığından, görüşülen kişiler titizlikle seçilmiş ve konu hakkında en doğru bilgilerin alınabileceği düşünülen kişiler tercih edilmiştir.

\subsection{Bulgular ve Değerlendirme Katılımcı Profili:}

Katılımc1 1, 2, 3, 4: Toyota Türkiye'de geçici süreliğine çalışmakta olan ve farklı bölümlerde görev yapan Japon koordinatörler.

Katılımc1 5: Toyota Türkiye'nin İK bölümünde çalışan ve bir süre işe alma kısmında görev yapmış olan Türk çalışan.

Katılımc1 6: Toyota Türkiye'nin İK bölümünde çalışan ve bir süre işe alma kısmında görev yapmış olan Japon çalışan. 
Katılımcı 7: İK bölümünden geçici süreliğine Toyota Japonya'da görev yapmış ve süresi dolup Türkiye'ye geri dönmüş olan Türk çalışan.

Katılımc1 8: Geçici süreliğine Toyota Japonya'da görev yapmış ve süresi dolup Türkiye'ye geri dönmüş olan Türk çalışan.

\section{Bulgular:}

Katılımcılara yöneltilen (Ek 1) sorular ve alınan cevaplar aşağıda çok temel kavramlar halinde kısaca aktarılmaya ve daha sonra alınan cevaplar doğrultusunda değerlendirme yapılmaya çalışılmıştır.

“Japon İKY anlayışının temel özellikleri nelerdir?" sorusuna verilen cevaplar aşağıdaki tabloda özetlenmiştir.

Tablo 2: Japon İKY Anlayışının Temel Özellikleri

\begin{tabular}{|l|l|}
\hline Katılımcı 1: & Çalışan odaklılık, süreç odaklı başarı ve sürekli ile tişim \\
\hline Katılımcı 2: & Çalışan başarısı, te crübe, yüksek he defler belirle mek, ile tişim, süre ç odaklılık \\
\hline Katılımcı 3: & Sorumlulukların eşit paylaştırılması ve çalışan odaklılık \\
\hline Katılımcı 4: & İletişim, yüksek he de fler belirlemek, tecrübe edindirmek ve başarı \\
\hline Katılımcı 5: & İnsana saygı, çalışan ihtiyaçları odaklılık, çalışanlarla ile tişim \\
\hline Katılımc1 6: & Sorumluluğun eşit öğretilmesi ve paylaştırılma sı, takım çalışması \\
\hline Katılımcı 7: & Temel Japon yönetim anlayışı İK da dahil tüm süreçlere yayılmış tır. \\
\hline Katılımcı 8: & Çalışan odaklı, çözüm üre tici, sorumluluklar belli ve net \\
\hline
\end{tabular}

Verilen cevaplara bakıldığında; tek başına ön plana çıan bir özelliğin olmadığı, buna karşılık "iletişim", "başarı" ve "sorumluluğun eşit paylaştırılması" gibi özellikler dikkat çekmektedir. Diğer özelliklerin katılımcılar tarafından dile getirilmesi göz önünde bulundurularak, Katılımc1 7'nin belirttiği gibi, temel anlayış İK'ya da yansımıştır denilebilir. “Toyota Türkiye'de IKY anlayışının
temel özellikleri nelerdir?” sorusuna
verilen cevaplar aşağıdaki tabloda
özetlenmiştir. 
Tablo 3: Toyota Türkiye'de İKY Anlayışının Temel Özellikleri

\begin{tabular}{|l|l|}
\hline Katılımcı 1: & Global Toyota İKY anlayışı ile aynı \\
\hline Katılımcı 2: & Toyota Ja ponya İKY anlayışı ile a ynı (ile tişim ve başarı ön planda) \\
\hline Katılımcı 3: & Genel Ja pon İKY anlayışı (sorumluluk ve ça lışana saygı) \\
\hline Katılımcı 4: & Çalışan odaklı (ça lışanın he defleri, başarısı, süreç ve ile tişim) \\
\hline Katılımcı 5: & Global Toyota İKY anlayışı (insana saygı, iletişim ve iyileştirme) \\
\hline Katılımcı 6: & Mavi yaka için Asya tipi, beyaz yaka için Avrupa tipi İKY \\
\hline Katılımcı 7: & Global Toyota İKY anlayışı, temel Ja pon yönetim anlayışı \\
\hline Katılımcı 8: & Sistemin yürütülmesi için çalışıllıor, iyileştirme ye terli değil \\
\hline
\end{tabular}

Verilen cevaplar katılımcıların yedi tanesinde ortaklık göstermekte, söz konusu katılımcılar Toyota Türkiye'nin İKY anlayışının Global Toyota İKY anlayışı ile aynı olduğunu belirtmektedirler. Buna karşılık sadece Katılımcı 6, Toyota Türkiye'de mavi yakalı personelin Asya tipi, beyaz yaka personelin ise Avrupa tipi yönetim anlayışı ile yönetildiğini düşünmektedir. Bunun sebebini ise; Toyota Türkiye'de İKY anlayışının Japonya kadar eski dönemlerden gelmemesi, Japon İKY anlayışının temel Japon yönetim tarzı ile birlikte var olduğu ve Toyota Türkiye'de ofis tarafinda Avrupa tipi yönetimin hakim olduğu şeklinde açıklamaktadır. Katılımcı 6 bu durumun, "Avrupa tipi yönetim anlayışı ile yönetilenlerin, Asya tipi yönetim tarzı ile yönetmesi" bakımından aslında bir çatışma sebebi olduğunu da vurgulamaktadır.

"Personel seçiminin Toyota Türkiye'de ve Toyota Japonya'da uygulanışı nasıldır?" sorusuna verilen cevaplar aşağıdaki tabloda özetlenmiştir.

\section{Tablo 4: Toyota Türkiye'de ve Toyota Japonya'da Personel Seçimi}

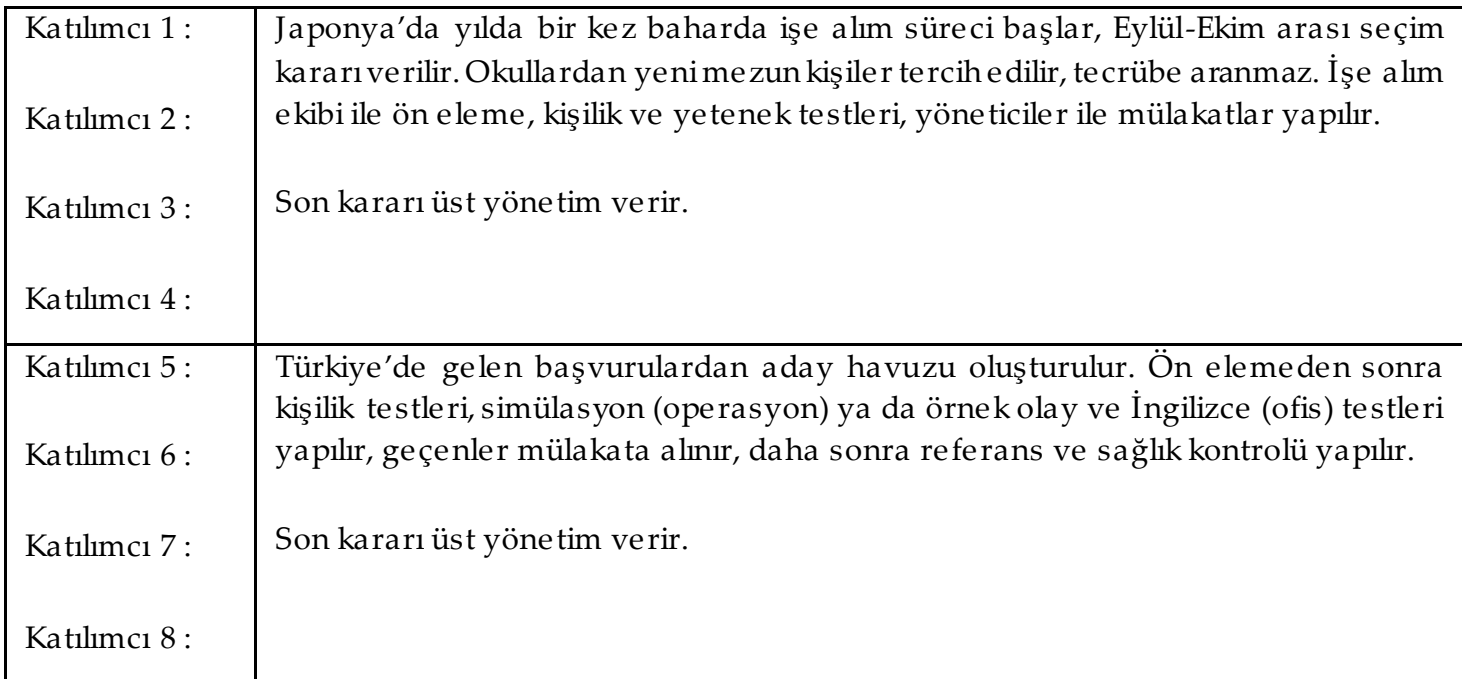



Verilen cevaplar Japon katılımcılar ve diğer katılımcılar (3 Türk, 1 Japon) olarak ikiye ayrılarak tablolaştırılmıştır. Bunun birinci sebebi, söz konusu katılımciların verdikleri cevapların ortak olması; ikinci sebebi ise, Toyota Japonya hakkındaki bilgilerin Japon katılımcilardan (Katılımcı 1, 2, 3 ve 4), Toyota Türkiye ile ilgili bilgilerin ise diğer katılımcılardan (Katılımcı 5, 6, 7 ve 8) alınmış olmasidir.

“Toyota Türkiye ve Toyota Japonya organizasyonları, personel seçimi bakımından farklılaşıyor mu? Neden?" sorusuna verilen cevaplar aşağıdaki tabloda özetlenmiştir.

Katılımcı 1, 2, 3 ve 4'ün Türkiye'de İKY ve işe alma yöntemleri hakkında, Katılımcı 8'in ise işe alma süreci hakkında yeterli bilgiye sahip olmamaları sebebi ile beşinci sorunun cevabı Katılımcı 5, 6 ve 7'den alınabilmiştir. Her üç katılımcı da Toyota Türkiye'nin İK çalışanı olduğundan, alınan cevapların genel bir yorum yapmaya elverişli olduğu düşünülmektedir.

Tablo 5: Personel Seçimi Bakımından Toyota Türkiye ve Toyota Japonya Farklılaşması

\begin{tabular}{|l|l|}
\hline Katılımcı 5: & $\begin{array}{l}\text { Farklılaşıyor. Çünkü iki ülkenin sosyo-kültürel, ekonomik yapıları, yasal } \\
\text { düzenlemeleri ve işsizlik oranları farklı. }\end{array}$ \\
\hline Katılımcı 6: & $\begin{array}{l}\text { Farklılaşıyor. Çünkü Toyota Japonya'da her kademedeki personel aynı süreçten } \\
\text { geçerekve aynı kriterlere (temel yetkinliklere) göre değerlendirilerek işe alınıor. } \\
\text { Oysa Toyota Türkiye'de mavi yaka ve beyaz yaka farklı kriterlere göre } \\
\text { değerlendiriliyor. Mavi yaka Asya tipi yönetim tarzına göre değerlendirilip } \\
\text { seçilirken, beyaz yaka Avrupa tipi yönetim tarzına göre yönetiliyor. Yani iki ülke } \\
\text { arasında seçim kriterleri farklılaşıor. }\end{array}$ \\
\hline Katılımcı 7: & $\begin{array}{l}\text { Farklılaşıor. Türkiye makro anlamda İKY sürecini iyi bilmiyor, Japonlarda ise İKY } \\
\text { Toplam Kalite ile birlikte çokeskilerden (1960'lardan) geliyor. Türk kültüründe “işe } \\
\text { adam almak" yerine "adama iş oluşturmak” anlayışı var. Ya da iş adama } \\
\text { uydurulur. Japonya'da ise adama göre iş konusu geçmez, şirket için adam aranır. }\end{array}$ \\
\hline
\end{tabular}

$\mathrm{Bu}$ soru, bir önceki sorunun devamı niteliği taşımaktadır. Bu soruya, yukarıda da belirtildiği gibi, Toyota Türkiye İK çalışanlarından cevap alınabilmiştir. Verilen tek cevap, personel seçimi bakımından Toyota'nın Japonya ve Türkiye organizasyonlarının farklılaştığıdır. $\mathrm{Bu}$ farklılaşmanın nedenleri üzerine verilen cevaplar ise farklılık göstermekte, her üç katılımcı da farklılaşmanın farklı nedenlerini vurgulamaktadır. Verilen cevaplara dayanarak farklılaşma nedenleri şöyle özetlenebilir:

- Sosyo-kültürel, ekonomik ve yasal düzenlemeler ile işsizlik oranları farklılıkları
- Seçim kriteleri farklılıkları

- İKY süreci ile kültür etkileşimi

\section{Değerlendirme:}

Personel seçimi ve işe alma süreci bakımından Toyota'nın Japonya ve Türkiye organizasyonları arasında farklılıklar olduğu yukarıda açıklanmıştı. İki organizasyon genel olarak işe alma sürecinin işleyişinde farklılaşmakta, ancak personel seçim kriterleri, bir başka ifade ile bakış açısı bakımından ortak bir yaklaşım sergilemektedir. Toyota için önemli olan, işe seçilecek kişinin genç, dinamik, öğrenmeye açık, eğitilebilir, takım 
çalışmasına yatkın ve sadık (şirkete bağlılık anlaminda) olmasidir. Genel olarak yeni mezun olmuş, iş tecrübesi olmayan kişiler tercih edilir, şirket içinde eğitilip yetiştirilir ve terfi ettirilir. $\mathrm{Bu}$, dışarıdan amir alınmadığı, yöneticilerin içeriden yetiştirildiği anlamına

Şekil 1: İşe Alımda T Modeli

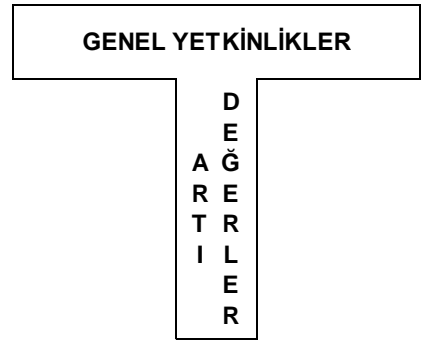

$\mathrm{Bu}$ modelde; sabır, analitik düşünebilme, takım çalışmasına yatkınlık, sahiplenme, aidiyet duygusu, objektif bakış açısı gibi potansiyel özellikler "Genel Yetkinlikler (yatay kısım)"; diploma notu, mezun olduğu üniversite, bildiği bilgisayar programları gibi özellikler ise "Artı Değerler (dikey kısım)" olarak görülmektedir. $\mathrm{T}$ modelinde önemli olan, kişinin genel yani temel yetkinliklere sahip, öğrenmeye açık ve eğitilebilir olmasıdır. Çünkü kişiler işe alındıktan sonra eğitilmekte, Toyota kültürü onlara anlatılmakta ve öğretilmektedir. Bu nedenle iş tecrübesi olmayan, yeni mezun kişiler tercih edilmektedir; çünkü yeni mezun kişi hamdır, şekil verilmemiştir ve eğitilmeye müsaittir; önemli olan kişinin Toyota yapısına uyum sağlayabilmesidir. Japon yönetim anlayışında farklı olmamak, sivrilmemek önem verilen bir değerdir. Şirketler, çalışanların kendilerini oraya ait hissetmelerini istemektedirler. Bu, takım çalışması mantığından gelmekte ve devamında da yine takım çalışmasına doğru gitmektedir.

\section{SONUÇ}

Seçim kriterleri bakımından ortak felsefeyi benimsemiş olsalar da işe alım süreci bakımından Toyota'nın Türkiye ve Jaoponya organizasyonları farklı uygulamalar gerçekleştirmektedir. gelmektedir. Bu sebeple adaylarda uzmanlık aranmaz. İşe başvuran adaylar; yatay kısmında genel yetkinliklerin, dikey kısmında ise adayın artı (+) değerlerinin yer aldığı $\mathrm{T}$ modeli bakış açısı ile değerlendirilmektedir.

Toyota Japonya'da adaylarla, daha okuldan mezun olmadan önce görüşülür. Burada en önemli etken, iş tecrübesi aranmamasıdır. Kalabalık bir ekip tarafından gerçekleştirilen ön elemelerden sonra işe alım kararı, birçok yönetici ile yapılan görüşmeler sonunda verilir. Kişi şirketin hangi bölümüne giderse gitsin çalışabilmeli, bunu sağlayacak temel yetkinliklere sahip olmalıdır. Bu nedenle örneğin, bir bilgisayar mühendisi finans bölümünde ya da bir endüstri mühendisi İK'da çalışabilir. Genel yetkinliklere sahip olması beklenen aday, şirketin her bölümünde istihdam edilmeye açık olmalıdır. İşe alım aşamasının son adımında karar genel müdür ve/veya genel müdür yardımcısı tarafından verilir.

Toyota Türkiye'de işe alım süreci, genel olarak Türkiye'de kurumsal şirketlerde uygulanmakta olan işe alım sürecidir. Teoride 8 temel adımdan oluştuğu bilinen bu süreç firmadan firmaya değişiklik göstermekle beraber, Toyota Türkiye'de tam anlamiyla uygulanıyor demek doğru olacaktır. Toyota Türkiye'de de yine şirket yapısına uyum sağlayabilecek, dinamik, iş tecrübesi olmayan ve öğrenmeye açı kişiler şirkete kazandırılmaya çalışılır. Bu sebeple de uzun soluklu bir seçim süreci bulunmaktadır. En doğru kararın verilebilmesi için aday birçok yetkili ve yönetici ile görüştürülür. İşe alımda son kararı yine genel müdür ve/veya genel müdür yardımcısı verir.

Sonuç olarak; çıkış noktası, Japon şirketleri ile Türk şirketlerinin İKY'de işe alma yöntemleri bakımından farklılaşıp farklılaşmadığı sorusu olan bu çalışmada, iki ülkenin farklılaştığı cevabına ulaşılmıştır.

Sözü edilen farklılaşmanın altında yatan nedenlere yönelik bir yorum yapılmak istenirse, şunlar söylenebilir: 
- İlk olarak, iki ülkenin iş hayatını düzenlemeye yönelik kanunları birbirinden farklıdır. Uluslararası İKY anlamında, var olması kaçınılmaz olan sebep, yasal düzenleme farklılıklarıdır denilebilir.

- İkinci olarak, iki ülke birbirinden sosyokültürel ve ekonomik alanda da farklıdır. Dolayısıyla ücret yapıları da birbirinden ayrılmaktadır. Toyota genel olarak belli bir seviyenin üzerinde maaş vermeye çalışır, ancak ülkeler arası ekonomik farklılıklar sebebi ile Türkiye ve Japonya organizasyonları arasında ücret politikalarına yönelik farklılıklar da görülmektedir.

- Üçüncü olarak, Japonya'da işsizlik oranının çok düşük olmasına karşılık, Türkiye'de bu oran oldukça yüksektir. Bu sebeple aday sayısı fazladır ve Toyota Türkiye de çok sayıda başvuru arasından en iyileri seçmeye çalışmaktadır. Japonya'da ise böyle bir durum söz konusu değildir. Dolayısıyla işe alım kriter ve yöntemleri ayrılmaktadır.

- Son olarak, iki ülke arasında eğitim ve istihdam politikaları bakımından da farklılıklar bulunmaktadır. Japonya'da

\section{KAYNAKÇA}

DANIŞMAN, Ali (2008), Türkiye'de İnsan Kaynaklan Yönetimi Uygulamalan, Nobel Kitabe vi.

DESSLER, Gary (1991), Personnel / Human Resource Management (Fifth Edition), Prentice Hall, New Jersey.

HATVANY, Nina ve V. Pucik (1991), "Japanese Management: Practices and Productivity", The Organizational Behavior Reader Fifth Edition, Editörler:David A. Kolb, Irwin M. Rubin ve Joyce S. Osland, Prentice Hall InternationalEditions, USA, s. 477-492.

KAYNAK, Tuğray (1996), "İnsan Kaynaklan Planlaması", Editör: Ramazan Geylan, İnsan Kaynakları Yönetimi, Anadolu Üniversitesi Yayını, Yayın No: 968, Eskişehir, s. 60-88.

KÜCÜ, Hüseyin (2007), Promethee Siralama Yöntemi Ile Personel Seçimi ve BirIş̧letmede Uygulanması, Basılmamış Yüksek Lisans Tezi, Gazi Üniversitesi Fen Bilimleri Enstitüsü.

MİRZE, S. Kadri (2010), İșletme, İstanbul Kültür Üniversite si, Literatür Yayıncıllk, İstanbul. istihdam politikası eğitim kurumlarını da kapsayarak ve hatta eğitim sisteminden beslenerek oluşturulmuşken; Türkiye'de, dev şirket denilen belli başlı büyük markalar dışında, böyle bir durum söz konusu değildir.

Tıpkı eğitim, sosyo-kültürel yapı ve ekonomik yapı gibi örgüt kültürü, yönetim anlayışı ve yönetim anlayışına bağlı olarak yürütülen tüm İKY fonksiyonları da toplumdan topluma değişmektedir. Bir toplumu var eden tüm düzenlemeler o topluma ait kültürden beslenerek oluşturulduğundan, sözü edilen farklılaşmanın olması kabul edilmelidir. Kültürün bu güçlü etkisi sebebiyle, tek bir şirketin farklı ülkedeki organizasyonları arasında bile yönetimsel ve işletimsel anlamda uygulama farklılıkları görülmesi kaçınılmazdır. Bu noktada karşımıza çıkan kavram da "uyum"dur. Bu sebeple uluslararası şirketler bakımından alınabilecek en doğru aksiyonun, kendi yönetim anlayışlarını konuk oldukları ülkenin toplumsal yaşantı ve kültürüne uyumlaştırmaya çalışmaları, olacağı düşünülmektedir.

MUCUK, İsmet (1999), Modern İsletmecilik, Türkmen Kitabevi, İstanbulÖZGEN, Hüse yin ve Azmi Yalçın (2010), Insan Kaynaklan Yönetimi Stratejik Bir Yaklaşım, Nobel Kitabevi, Adana.

PUDELKO, Marcus (2006), "A Comparison Of HRM Systems In The USA, Japan

and Germany In Their Socio-Economic Context", Human Resource

Management Journal, Vol:16, Issue:2, s. 123-153.

ROBINSON, Patricia A. (2003), "The Embeddedness of Japanese HRM Practices:The Case Of Recruiting", Human Resource Management Review, Vol: 13, Issue: 3, s. 439-465.

SABUNCUOĞLU, Zeyyad (2000), Insan Kaynaklan Yönetimi, Ezgi Kitabevi, Bursa

TÜZ, Melek Vergiliel (2001), Japon ve Amerikan Yönetim Modeli (Türkiye Uygulaması), Alfa Yayınları, İstanbul.

YOSHINO, M.Y. (1968), Japan's Managerial System, Tradition and Innovation, The MIT Press, U.S.A. 